\title{
Study on fetomaternal outcome in antepartum haemorrhage
}

\author{
Naimish D. Nathwani*, Rupa C. Vyas, Sapana R. Shah, Purvi M. Parikh
}

Department of Obstetrics and Gynecology, Smt. N. H. L. Municipal Medical College, Ahmedabad, Gujarat, India

Received: 24 August 2020

Revised: 05 October 2020

Accepted: 06 October 2020

\section{*Correspondence:}

Dr. Naimish D. Nathwani,

E-mail: nathawaninaimish123@gmail.com

Copyright: ( $)$ the author(s), publisher and licensee Medip Academy. This is an open-access article distributed under the terms of the Creative Commons Attribution Non-Commercial License, which permits unrestricted non-commercial use, distribution, and reproduction in any medium, provided the original work is properly cited.

\begin{abstract}
Background: Any bleeding from or into the genital tract after the period of viability, but before the birth of the baby is termed as antepartum haemorrhage (APH).

Methods: 110 cases of bleeding per vaginal (pv) after 28 weeks of gestation were studied retrospectively from August 2018 to June 2019 and were grouped as placenta previa, placental abruption and indeterminate.

Results: $35.45 \%$ cases were of placenta previa, $53.63 \%$ cases were of placental abruption and $10.90 \%$ cases were of indeterminate. Majority were delivered by lower segment caesarean section (LSCS) and most of the cases required blood transfusion.

Conclusions: APH cannot reliably be predicted .It is major cause of maternal and perinatal mortality and morbidity. Multidisciplinary approach and senior input is necessary in making decision about timing and mode of delivery. Presently increase in use of ultrasonography (USG) for placental localisation and to diagnose abruption, improved obstetrical and anesthetic facilities, increase in use in blood products to correct anemia and advanced neonatal care facilities, all of these have played important role in decreasing perinatal as well as maternal mortality and morbidity.
\end{abstract}

Keywords: Placenta previa, Placental abruption, Antepartum haemorrhage

\section{INTRODUCTION}

Antepartum haemorrhage (APH) has always been one of the most feared complications in obstetrics.

APH is defined as any bleeding from or into the genital tract after the period of viability, but before the birth of the baby. 1 On an average 2 to $5 \%$ of all pregnancies are complicated by antepartum haemorrhage. ${ }^{1,2}$

The main cause of APH is placenta previa and abruption placentae. In a small proportion where placenta previa and abruption have been excluded, the cause may related to local lesions of the cervix and vagina, e.g. cervicitis, cervical erosion, genital tumours, vaginal varicosities, rupture of vasa previa and heavy show. The prevalence is approximately $0.5 \%$ of all pregnancies, and this increase correlates to the elevated cesarean section rate. ${ }^{3}$
Abruption is more likely to be related to condition occurring during pregnancy (preeclampsia, abdominal trauma, intrauterine infections, premature rupture of membranes, polyhydroamnios, smoking and substance abuse) and placenta previa related to condition existing prior to the pregnancy (uterine scar manual removal of placenta, curettage, advanced maternal age, multiparity and previous placenta previa).

The maternal complications in patients with APH are malpresentations, preterm labour, postpartum haemorrhage, septic, shock and retained placenta. Various fetal complications are preterm birth, low birth weight, intrauterine death, congenital malformations and birth asphyxia.

In developing countries, wide spread pre-exisitng anemia, difficulties with transport, restricted medical facilities, 
decrease awareness in part of patients are responsible for high maternal mortality rate (MMR). Obstetrical haemorrhage along with hypertension and infections is one of the infamous triad of causes of maternal death in both developed and developing country. Prompt diagnosis, resuscitation and management are essential to save the mother and the fetus.

Objective of the study were to study the prevalence of APH at tertiary care hospital, to assess the importance of early diagnosis and treatment, to study the maternal and fetal outcome in APH and to study the associated risk factor contributing to maternal and fetal morbidity and mortality.

\section{METHODS}

A retrospective study was conducted from August 2018 to June 2019 at tertiary care centre. 110 cases of bleeding per vaginal (pv) after 28th weeks of gestation were studied for fetomaternal outcome. Informed consent was taken from all patients.

\section{Inclusion criteria}

Any bleeding from or into the genital tract after $28^{\text {th }}$ week of pregnancy and before birth of baby.

\section{Exclusion criteria}

Patient with bleeding due to any another cause (bleeding disorder).

Antenatal patients with bleeding pv less than $28^{\text {th }}$ week of gestation.

Source of bleeding other than uterus.

Female fulfilling the above criteria were included in study. Detailed history was taken and clinical examination was done, including general examination, per abdominal examination, per speculum examination and $p v$ examination (when required). Basic obstetrics ultrasound was done to know fetal well-being, gestational age, amniotic fluid and most importantly for localization of placenta and to see any blood collection behind the placenta. Various blood and other investigations were carried out like complete blood count, coagulation profile, renal function test, liver function test, lactate dehydrogenase (LDH), uric acid, and urine albumin. Subsequent management was done according to the type of APH (i.e. placenta previa, and abruption placentae), severity and type of bleeding and gestational age.

\section{RESULTS}

110 cases of APH were analyzed in which $35.45 \%$ cases were of placenta previa, $53.63 \%$ cases were of abruptio placentae and $10.90 \%$ were indeterminate.

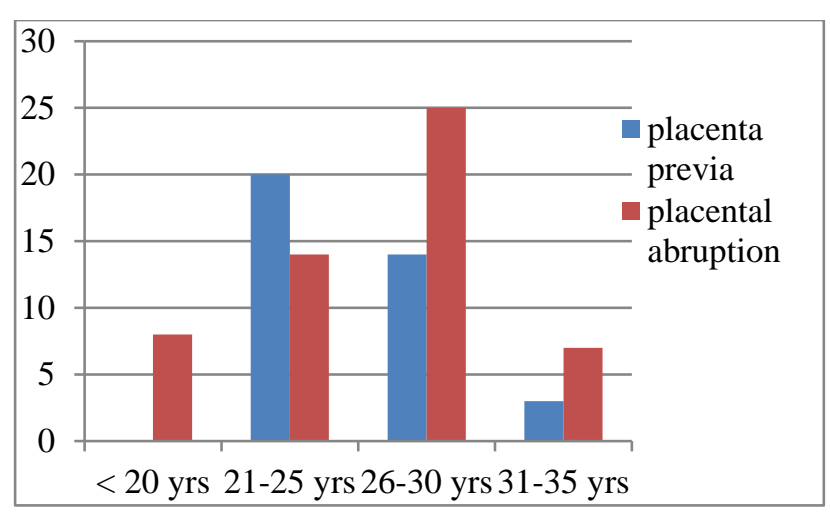

Figure 1: Age distribution.

Table 1: Gravida distribution.

\begin{tabular}{|lll|}
\hline Distribution & $\begin{array}{l}\text { Placenta previa } \\
(\mathbf{n = 3 9})\end{array}$ & $\begin{array}{l}\text { Abruption } \\
\text { placentae }(\mathbf{n}=\mathbf{5 9})\end{array}$ \\
\hline Primi & $8(20.51)$ & $20(33.89)$ \\
\hline Gravida 2 & $12(30.76)$ & $11(18.64)$ \\
\hline Gravida 3 & $11(28.20)$ & $14(23.72)$ \\
\hline Gravida 4 & $6(15.38)$ & $7(11.86)$ \\
\hline $\begin{array}{l}\text { Gravida 5 or } \\
\text { more }\end{array}$ & $3(7.69)$ & $4(6.77)$ \\
\hline
\end{tabular}

Table 2: PIH and antepartum haemorrhage.

\begin{tabular}{|lll|}
\hline & $\begin{array}{l}\text { Placenta previa } \\
(\mathbf{n}=\mathbf{3 9})\end{array}$ & $\begin{array}{l}\text { Placental abruption } \\
(\mathbf{n}=\mathbf{5 9})\end{array}$ \\
\hline PIH & $2(5.12)$ & $21(35.59)$ \\
\hline
\end{tabular}

In current study it was found that pregnancy-induced hypertension (PIH) was more associated with placental abruption rather than that of placenta previa.

Table 3: Mode of delivery.

\begin{tabular}{|lll|}
\hline $\begin{array}{l}\text { Mode of } \\
\text { delivery }\end{array}$ & $\begin{array}{l}\text { Placenta previa } \\
(\mathbf{n = 3 9})\end{array}$ & $\begin{array}{l}\text { Placental } \\
\text { abruption }(\mathbf{n}=\mathbf{5 9})\end{array}$ \\
\hline LSCS & $39(100)$ & $38(64.40)$ \\
\hline $\begin{array}{l}\text { Normal } \\
\text { delivery }\end{array}$ & 0 & $21(35.59)$ \\
\hline
\end{tabular}

During current study it was also found that no cases of placenta previa were delivered vaginally, while in cases of placenta abruption rate was of normal vaginal delivery was of $35.59 \%$ (21 case).

Table 4: Maternal complications.

\begin{tabular}{|lll|}
\hline $\begin{array}{l}\text { Complica- } \\
\text { tions }\end{array}$ & $\begin{array}{l}\text { Placenta } \\
\text { previa }(\mathbf{n = 3 9})\end{array}$ & $\begin{array}{l}\text { Placental } \\
\text { abruption }(\mathbf{n}=\mathbf{5 9})\end{array}$ \\
\hline PPH & $10(25.64)$ & $11(18.64)$ \\
\hline DIC & $4(10.25)$ & $10(16.94)$ \\
\hline ARF & $1(2.56)$ & $7(11.86)$ \\
\hline $\begin{array}{l}\text { Couvelaire } \\
\text { uterus }\end{array}$ & 0 & $8(13.55)$ \\
\hline
\end{tabular}


Table 5: Per operative intervention.

\begin{tabular}{|lll|}
\hline $\begin{array}{l}\text { Per operative } \\
\text { intervention }\end{array}$ & $\begin{array}{l}\text { Placenta } \\
\text { previa } \\
(\mathbf{n = 3 9})\end{array}$ & $\begin{array}{l}\text { Placental } \\
\text { abruption } \\
(\mathbf{n = 5 9 )}\end{array}$ \\
\hline Blood transfusion & $33(84.61)$ & $45(76.27)$ \\
\hline $\begin{array}{l}\text { B/L uterine artery } \\
\text { ligation }\end{array}$ & $9(23.07)$ & $12(20.33)$ \\
\hline Caesarean hysterectomy & $5(12.82)$ & 0 \\
\hline
\end{tabular}

Table 6: Perinatal and neonatal outcome in antepartum haemorrhage.

\begin{tabular}{|lll|}
\hline Outcome & $\begin{array}{l}\text { Placenta previa } \\
(\mathbf{n = 3 9})\end{array}$ & $\begin{array}{l}\text { Placental } \\
\text { abruption }(\mathbf{n = 5 9})\end{array}$ \\
\hline Preterm & $34(87.17)$ & $40(67.79)$ \\
\hline Term & $6(15.38)$ & $17(28.81)$ \\
\hline $\begin{array}{l}\text { Low birth } \\
\text { weight }\end{array}$ & $25(64.10)$ & $21(35.59)$ \\
\hline IUD & $3(7.69)$ & $16(27.11)$ \\
\hline $\begin{array}{l}\text { Neonatal } \\
\text { death }\end{array}$ & $3(7.69)$ & $3(5.08)$ \\
\hline $\begin{array}{l}\text { NICU } \\
\text { admission }\end{array}$ & $11(28.20)$ & $14(23.72)$ \\
\hline
\end{tabular}

Table 7: Investigations.

\begin{tabular}{|c|c|c|}
\hline Investigations & $\begin{array}{l}\text { Placenta } \\
\text { previa } \\
(\mathbf{n}=39)\end{array}$ & $\begin{array}{l}\text { Placental } \\
\text { abruption } \\
(\mathbf{n}=\mathbf{5 9})\end{array}$ \\
\hline Hb $(<8)$ & $7(17.94)$ & $18(30.50)$ \\
\hline Urine albumin (+) & $8(20.51)$ & $24(40.67)$ \\
\hline $\begin{array}{l}\text { Prothrombin time } \\
(>14)\end{array}$ & $23(58.97)$ & $27(45.76)$ \\
\hline $\begin{array}{l}\text { Argon plasma } \\
\text { coagulation }(<1,00,000)\end{array}$ & $2(5.12)$ & $5(8.47)$ \\
\hline
\end{tabular}

\section{DISCUSSION}

In our study $35.45 \%$ cases were of placenta previa and $53.63 \%$ cases were of placental abruption, more cases were of placental abruption, however in Maurya et al and Adekanle et al study more cases were of placenta previa.,

In present study age distribution shows that $35.45 \%$ of APH lies between 26-30 years especially placental abruption i.e. $42.37 \%$, which is same as study by Adekanle et al in which $40 \%$ APH patients were between $25-29$ years of age (Figure 1). ${ }^{5}$

In current study placental abruption was more common in primis as compared to placenta previa $(33.89 \%$ in placental abruption and $20.51 \%$ in placenta previa), also in studies of Arora et al, Pandey et al and Maurya et al study abruption was more in primigravida (Table 1).,4,7

In present study of APH $38.46 \%$ cases were of major placenta previa and $61.53 \%$ were of minor type of placenta previa, and also in case of placental abruption $18.64 \%$ cases had concealed haemorrhage, $25.42 \%$ cases had reavealed haemorrhage and $54.23 \%$ had mixed type of haemorrhage.

Pregnancy-induced hypertension (PIH) was present in majority cases of placental abruption i.e. $35.59 \%$ while only $5.21 \%$ cases of placenta previa had PIH, comparable to study done by Tyagi, Yadav, Sinha and Gupta in which $11 \%$ cases of placental abruption had PIH (Table 2). ${ }^{8}$

In current study $70 \%$ cases of APH were delivered by lower segment cesarian section (LSCS) and $19.09 \%$ cases by vaginal route. $100 \%$ cases of placenta previa were delivered by LSCS, where as in case of placental abruption $64.40 \%$ were delivered by LSCS and $35.59 \%$ cases by vaginal route. The above result of mode of delivery is comparable to Maurya et al study in which there is $94.3 \%$ LSCS rate in APH (Table 3). ${ }^{4}$

In our study PPH was a major intrapartum complication involving $19.09 \%$ cases of APH. $25.64 \%$ cases of placenta previa and $18.64 \%$ cases of placental abruption. DIC was present in $10.25 \%$ cases of placenta previa and $16.94 \%$ cases of placental abruption, whereas acute renal failure (ARF) was present in $7.27 \%$ cases of APH (Table 4).

Blood transfusion was required intraoperatively in $70.90 \%$ of total APH patients with $84.61 \%$ of placenta previa and $76.27 \%$ of placental abruption cases requiring blood transfusion. Bilateral (B/L) uterine ligation was performed in $19.09 \%$ cases of APH, $23.07 \%$ in placenta previa and $20.33 \%$ in placental abruption. Caesarean hysterectomy was performed in $4.54 \%$ cases of APH and all were performed in placenta previa, which is similar to the study of Nasreen et al in which incidence was $5 \%$ (Table 5). ${ }^{9}$

$67.27 \%$ cases of APH had preterm delivery, with $87.17 \%$ rate in placenta previa and $67.79 \%$ rate in placental abruption. Similar results were appreciated in study by Maurya et al in which $52 \%$ patients delivered before 37 weeks with majority being cases of placenta previa. ${ }^{4}$ Also in our study $22.72 \%$ fetus had required neonatal intensive care unit (NICU) admission (28.20\% in placenta previa and $23.72 \%$ in placental abruption), and $17.27 \%$ was intrauterine device (IUD) $(7.69 \%$ in placenta previa and $27.11 \%$ in placental abruption) (Table 6).

In current study $6.36 \%$ cases of APH had argon plasma coagulation (APC) less than 1,00,000 out of which $5.12 \%$ cases in placenta previa and $8.47 \%$ in placental abruption, also in majority cases prthrombin time (PT) $>14$ sec i.e. $45.45 \%$ cases of APH $(58.97 \%$ in placenta previa and $45.76 \%$ in placental abruption) (Table 7 ).

\section{CONCLUSION}

APH cannot reliably be predicted. It is major cause of maternal and perinatal mortality and morbidity. Multidisciplinary approach and senior input is necessary in making decision about timing and mode of delivery. 
Presently increase in use of ultrasonography for placental localisation and to diagnose abruption, improved obstetrician and anesthetist facilities, increase in use in blood products to correct anemia and advanced neonatal care facilities, all of these have played important role in decreasing perinatal as well as maternal mortality and morbidity.

Funding: No funding sources

Conflict of interest: None declared

Ethical approval: The study was approved by the Institutional Ethics Committee

\section{REFERENCES}

1. Mishra R. Ian Donald's Practical Obstetric Problems. Seventh edition. Lww Rs Elite. 2014;315-28.

2. Bhide A, Thilaganathan B. Recent advances in the management of placenta praevia. Curr Opin Obstet Gynecol. 2004;16:447-51.

3. Cunningham FG, Leveno KJ, Bloom SL, Spong CY, Dashe JS, Hoffman BL, et al. Obstetrical hemorrhage. Williams Obstetrics, 23rd ed. New York: McGrawHill. 2009;757-803.

4. Maurya A, Arya S. Study of Antepartum Haemorrhage and Its Maternal and Perinatal Outcome. Int J Sci Res Publ. 2014.
5. Adekanle DA, Adeyemi AS, Fadero FF. Antepartum haemorrhage and pregnancy outcome in Lautech teaching Hospital, southwestern Nigeria. J Med Sci. 2011;1243-7.

6. Arora R, Devi U, Majumdar K. Perinatal morbidity and mortality in antepartum haemorrhage. J Obstet Gynae India. 2001;51(3):102-4.

7. Pandey VP, Pandey M. Study of antepartum haemorrhage and its maternal and perinatal Outcome 2016. Available

at: http://imsear.li.mahidol.ac.th/handle/12345489/1757 84. Accessed on: 25 July 2020.

8. Tyagi P, Yadav N, Sinha P, Gupta U. Study of antepartum haemorrhage and its maternal and perinatal outcome. Int $\mathbf{J}$ Reprod Contracept Obstet Gynecol. 2016;5:3972-7.

9. Nasreen F. Incidence, Causes and outcome of placenta previa. J Postgrad Med Inst Peshawar - Pak. 2003;17(1).

Cite this article as: Nathwani ND, Vyas RC, Shah SR, Parikh PM. Study on fetomaternal outcome in antepartum haemorrhage. Int $\mathbf{J}$ Reprod Contracept Obstet Gynecol 2020;9:4554-7. 